農業情報研究 12 （1）、2003. 33-44

\title{
原著論文
}

\section{DNA アルゴリズム}

\author{
岡山 毅・北端啓司・村瀬治比古 \\ 大阪府立大学大学院農学生命科学研究科 $\bar{T}$ 599-8531 堺市学園町 1-1
}

\section{要旨}

農学分野の多くの問題は非線形性が強く, また, 解候補数も莫大であることが多い. そのような問題に 対しては従来の決定論的な計算手法による解析が困難である場合が多い.それらの問題を解くもしくは 近似解を得る手法として注目を集めているのが, 適応的あるいは知能的手法で生物系由来アルゴリズム である遺伝的アルゴリズム (GA) や人エニューラルネットワーク (ANN) である. 本研究で開発したDNA アルゴリズムは (DNAA)，GA やANN と同様な生物系由来アルゴリズムである，GA とDNAAの違いは，GA がエキソンのみを考慮に入れているのに対し，DNAA は，エキソンのみならずイントロンも最適化に貢 献する要素として取り入れたことにある. エキソンとはタンパク質合成に必要な塩基配列であり,イン トロンとはタンパク質の合成の際に情報源として用いられない塩基配列である.イントロンの役割は未 だ解明されていないが, その重要な役割の一つが, 突然変異による致命的な遺伝情報の破壊を減少させ ることにあるといわれている. 本研究では, 人工生命を用いてこの仮定を検証し, そして文字列探索問 題とナップザック問題を用いてDNAA の性能を評価した. その結果，エキソンによる突然変異に対する 防御が, 人工生命が繁殖する上で良い効果を与えていること, そしてより重要度の高いエキソンにより 長いイントロンが付加すること, そしてDNAA，GA と比較し高い突然変異率に対してより安定した推 定が行えることが明らかとなった.

キーワード

イントロン，遺伝的アルゴリズム，人工生命，DNA

\section{はじめに}

孔雀の羽の美しさやキリンの首の長さなどを みると, 生物の進化過程で起きる淘汰や突然変 異等による環境適応のための最適化プロセスが 自然界に存在することが同える. このような生 物が行っている最適化プロセスをもとに離散的 最適化問題における効果的な計算システムを実 現するために開発されたものが生物系由来アル ゴリズムの代表例である遺伝的アルゴリズム (Genetic Algorithms：GA）である. 遺伝的アル ゴリズムは, 最適化問題の解法, 人工知能の学 習, プログラムの自動合成, 経済市場のモデル化 あるいは人工生命などに広く応用されている.

生物は数多くのタンパク質によって生命活動 を維持しているが，DNAにはタンパク質の情報が わずか 4 種類の塩基 $\mathrm{A}:$ アデニン, $\mathrm{T}:$ チミン, $\mathrm{G}$ : グアニン, C : シトシンの組み合わせによって記
されている. DNAの塩基配列には, タンパク質の 合成の際に用いられないイントロンと呼ばれる 塩基配列が，タンパク質の設計図であるエキン ンと呼ばれる塩基配列を分断するように挟まっ ている. 生物の体内でタンパク質を合成する必 要が生じると, DNA から RNA 情報が転写され, さらにRNA 上のイントロンを取り除き，エキソ ンだけをつなぐスプライシングという作業に よって, タンパク質の設計図である $\mathrm{m} \mathrm{R} \mathrm{N} \mathrm{A}$ (messenger RNA) がつくられる. 真核生物の DNA 全体を見てみると，エキソン部分はイントロン 部分に比べてごくわずかである．たとえばヒト の場合, 全DNA の塩基配列の 95〜97 パーセント 以上がイントロンといわれている. 逆にバクテ リアなどの原核生物には, 非常に単純で利用率 の高いDNA 情報が備わっており，一般的に単純 
な生物ほどイントロンの割合は小さい．何故こ のような”ムダ"が存在するのかは様々な説が存 在するがその一つに次のような説がある（スミ ス 1995). 生物は, 太陽からの紫外線, 環境をと りまく有害物質，放射線などの外的要因や，DNA 転写の際のコピーミスによって, 突然変異が DNA の塩基配列のどの部分に起こるかは，基本的に ランダムである。また，塩基閒のつながり，つま りDNA 鎖の切れにくさは一様であると考えられ る．仮にDNAの寸べてが意味のある重要な情報を 持っているとすると，わずかな変化が起きただ けで重大な問題を引き起こすと予想される。し かし，DNA 中にイントロンが十分にあれば，重要 なエキソンが傷つく可能性は低くなる。大切な 情報と一緒に無駄なものをあえて保持すること で，情報が伝達される過程での情報の正確さを 確保することができる．生物は突然変異による 悪影響を緩和するために，進化の過程でイント ロンの増加という遺伝的冗長性を獲得していっ たと考えられる（スミス 1995，小香 1998）。そ こで, 本研究ではイントロンによる遺伝的冗長 性と生物の形質の関係について簡単な人工生命 老用いて検討し，その結果を基にDNAアルゴリズ ムを開発した。また，文字列探索問題とナップ ザック問題を用いて，DNAアルゴリズムの特徴を 検討した。

\section{人工生命を用いたイントロン挿入効果の検証}

\section{人工生命}

人工生命研究の目標は, 生命老特徵付ける現 象，寸なわち，遺伝的情報から生物個体への発 生, 環境中での適応, 学習, 進化, 棲み分け, 寄 生共生，自律分散などを，一般的なシステムの枠 組みの中で定式化することにある（北野 1993， 伊庭 1994）。人工生命の定義として，1）一つの 個体に関してのプログラムは，他の個体との遭遇 などの環境内の局所的な状況に反応する仕方を記 述する．2）全体的な行動を規定する規則は存在 しない。などがある。

\section{適用した人工生命}

本研究では，3つの特徵を持った人工生命を用
いた. 図 1 は $200 \times 200$ のセルで構成される人工 生命が活動する領域を表す。さらに，領域を 20 $\times 20$ に分割し, その領域每に, 食料が供給され, その量は背景色の濃淡で表される。 それぞれの 生命体は丸い点で表されている.

\section{生命体の特徵}

人工生命の特徵は, 行動, 体色, そしてサイズ の 3 つがあり，それぞれ0から7の8 段階の值で 表される。

a）行動・・・早の個体が今までの進行方向に対 してそのまま直進するか，右か左に方向転換 するかを確率で表現したものである．直進す る確率は, $(1 （$ 行動值 +1$))$ で表現される. つまり，行動值が大きいほど直進する確率が 低くなる。

b）体色・・個体が成熟しているときに，違う成 熟した個体と近接した場合, 新たな個体を産 む. 派手な体色の個体の場合, 相手との距離が 離れていても生殖できるのに対し, 地味な体 色の個体では，上り近づかなければ生殖を行

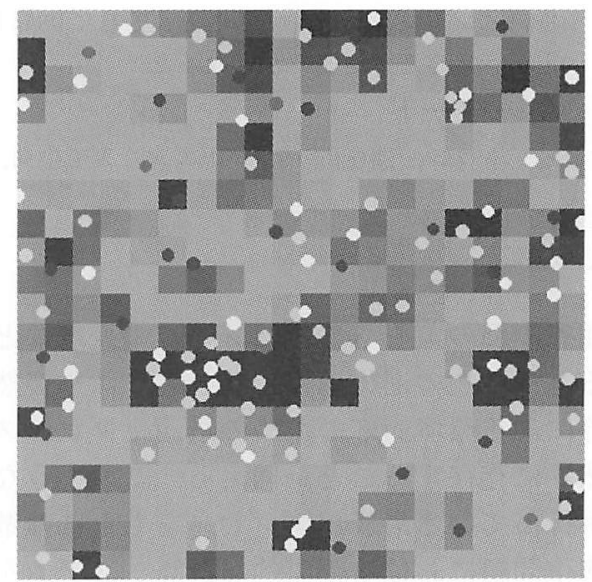

図 1 人工生命活動領域

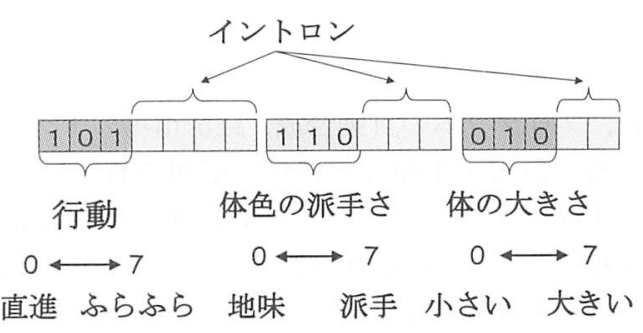

図2 DNAモデル 
うことができない。一方，派手なほど天敵にも 見つかり易いという不利益もある，生殖及び， 被食距離は，(体色值+1）で表される。

c）サイズ・・・体の大きさを表す。大きいほど エネルギーの消費が激しいが，天敵と遭遇し た場合，大きいほど被食率が低い、エネルギー 消費量は，(サイズ值＋1）とし，被食率は，(1) エネルギー消費量）とする.

DNAモデル

本研究で用いた個体のDNA モデルを図 2 に示 すそそれぞれのパラメータは，0〜7の8段階で 表現されるのため, 3 ビットで表現される. 例え ば，図 2 の DNA モデルを持つ個体の場合，行動值 は 5 ，すなわち直進する確率が $1 / 6$ であるので，や や”ふらふら”する傾问にあるといえる. 次に体
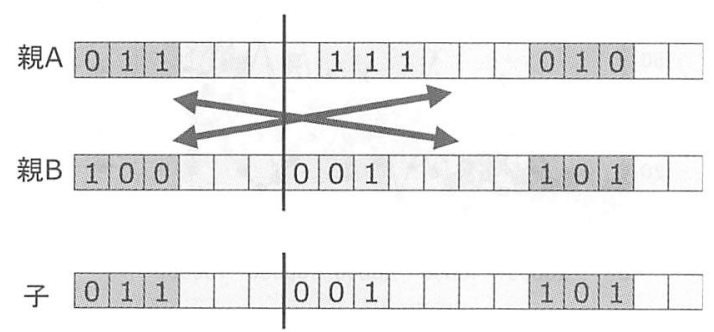

図3 生殖

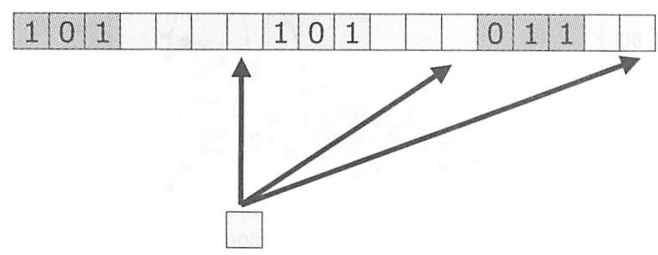

図 4 イントロンの挿入

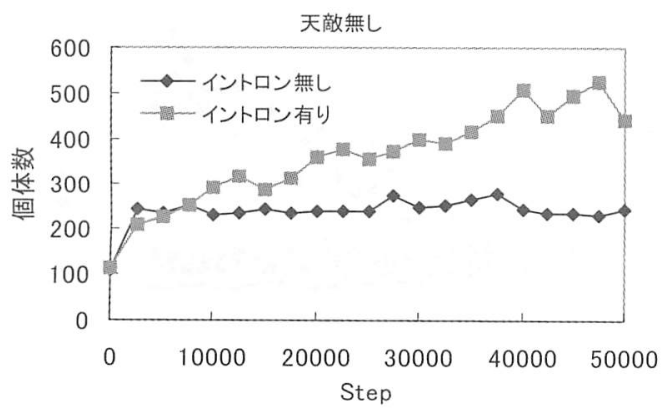

色值は 6 であるので生殖及び被食距離は 7 であ る，サイズ值は，2 であるのでエネルギー消費量 が 3 , 被食確率が $1 / 3$ となる。 また，イントロン がそれぞれのエキソン部を保護するように付随 している.

生命体の状態変化と天敵

人工生命体は，以下の状態をとる.

a）未成熟の個体・・・生まれたばかりで生殖能 力がない、しばらくすると状態 $\mathrm{b} に$ に移る。

b）成熟した個体・・・生殖能力がある。他の成 熟した個体と近接すると（その距離は，その 個体の体色に依存する）生殖をおこない新し い個体を生成寸る。生殖後, 状態 $\mathrm{c}$ に移る。こ の人工生命体には，雌雄の別はない，

c）生殖直後の個体・・・生殖能力がない.しば らく経過すると状態 $\mathrm{b}$ に戻る.

さらに, 活動領域には，天敵が存在しうる。 天 敵は個体に近接すると（その距離は，その個体の 体色に依存する）捕食する.

生殖とイントロン延長

個体が成熟した状態にあり，他の成熟した個 体に近接した場合，生殖が行われ，新たな個体 が誕生する。新たな個体は，親である個体の DNA コードを1 点交叉したものを受け継ぐ、イント ロンも同じように受け継がれ，その時ある確率 でランダムに，3つのイントロンのうちのひと つを延長する。

笑然変異

フィールドに存在する全ての個体は，ある確 率で突然変異索受ける。あるエキソン部が突然 変異する確率は, 以下のように計算される. エキソン部が変異する確率 $=\frac{\text { 突然変異率 }}{\text { イントロン長 }}$

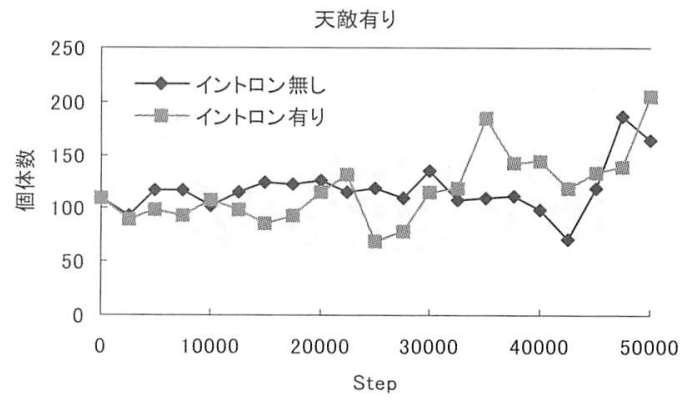

図 5 個体数変動 
つまり，エキソン部に付随するイントロン長が長 いほど, 変異率が低下する.

\section{実験1}

この人工生命を使い，イントロンの有無によっ て，個体数と個体の特徴がどのように変化するの かを検討した. 環境設定は, 初期集団数 100 , 突 然変異率 0.005 とし, 食料供給量を変えた場合, 天敵が存在しない場合と存在する場合を行った.

\section{実験1の結果および考察}

天敵が存在しない場合

図 5 左に食糧供給量が 15 で天敵が存在しない
場合のイントロンが有る場合と無い場合の個体 数変化を, 図6に特徵の值ごとの個体数変化を示 す. 個体数は，イントロンが有る場合の方がイン トロンが無い場合に比べ，個体数が多くその差 はステップが進むにつれて徐々に大きくなって いる.この理由として，イントロンが無い場合だ と自然淘汰によって選ばれた環境に適した特徵, サイズでいえば 0 もしくは 1 ，が突然変異によっ て変えられて生存できないためだと考えられる. その一方で，イントロンが有る場合，それらの特 徵がイントロンが存在することにより突然変異 から守られるので，より個体数を増加させるこ とができると考えられる." 行動”については,
行動 イントロン無し

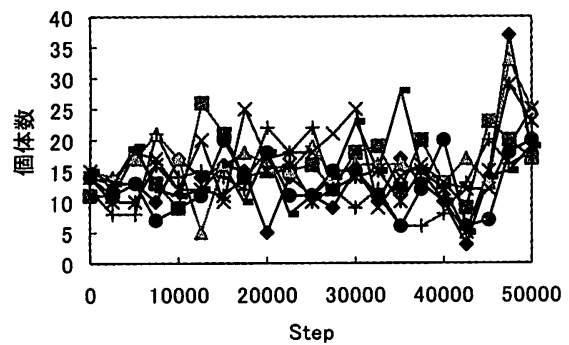

体色 イントロン無し

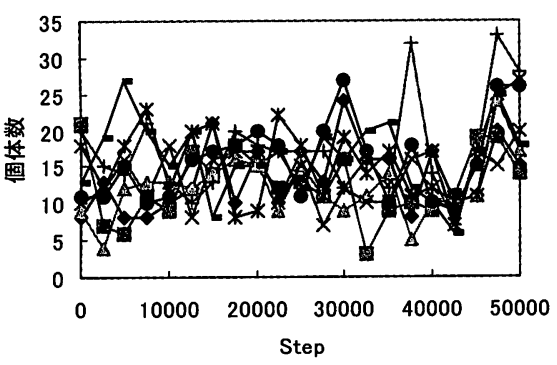

サイス イントロン無し

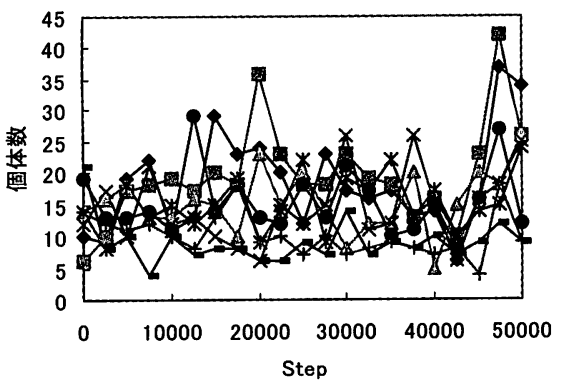

行動 イントロン有り
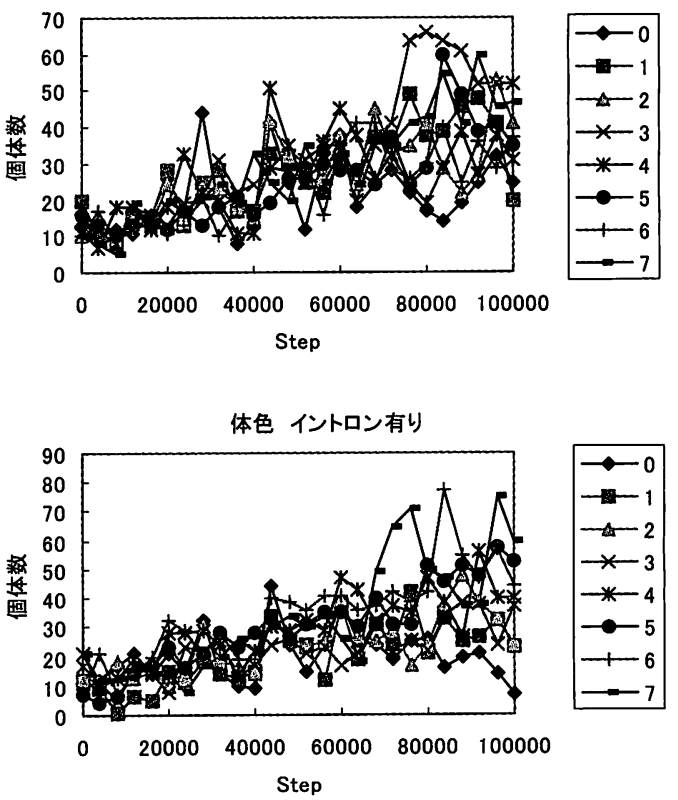

サイズ イントロン有り

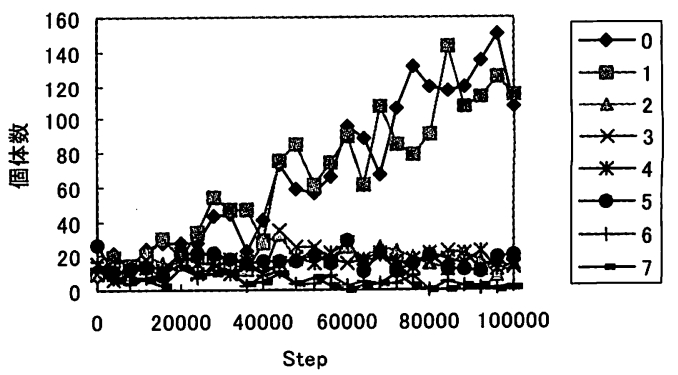

図 6 天敵が存在しない場合の各特徴動向 
イントロンが無い場合では行動様式による特徴が 明確ではないが，イントロンが有る場合を見れ ば，直進性の高い個体が優勢になっている．直進 性が高い個体が優勢な理由は，ふらふらする個体 が同じ領域にとどまって，食糧を食べ尽くし餓死 する可能性が高いのに対し, 直進性の高い個体 は，食糧を食べ尽くす前に，別の領域に移動でき るので餓死しにくいためだと考えられる．体色で は，イントロンが有る場合は，派手な個体が，生 殖を行う際に有利であるために優勢になってお り，その度合いはステップが進むにつれて高く なっている."サイズ"では, イントロンが無い 場合でも, 小さい方が優勢であるのがよく分か
る.イントロンが有る場合にはその傾向がより 顕著になり,"サイズ"0, 1 以外の個体はほとん どいなくなっている. 以上の結果からイントロ ンは淘汰によって選ばれた形質を突然変異から 守り, 種が繁栄するのに貢献しているといえる.

図8左は, 天敵が存在しない場合の食料環境の 違いによるイントロン付加割合をあらわしてい る. イントロン付加割合は, 20,000 ステップ後 に生き残った個体のそれぞれの特徵を表すエキ ソンに付加しているイントロン長を全てのイン トロン長の合計で割ったものである.この図か ら, 生き残った個体のイントロン長は, "サイズ ", "行動", "体色"の順であることが分かる. イ
行動 イントロン無し

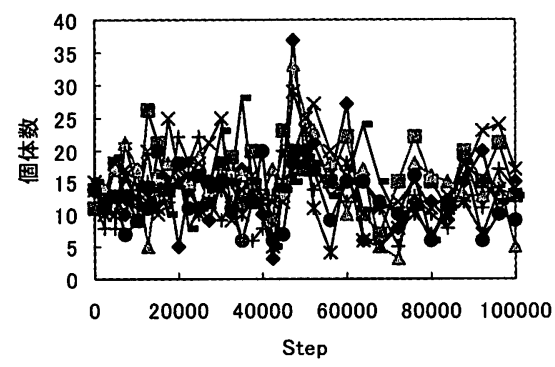

体色 イントロン無し

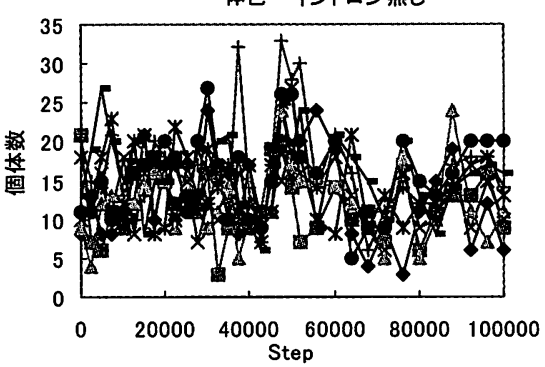

サイズ イントロン無し

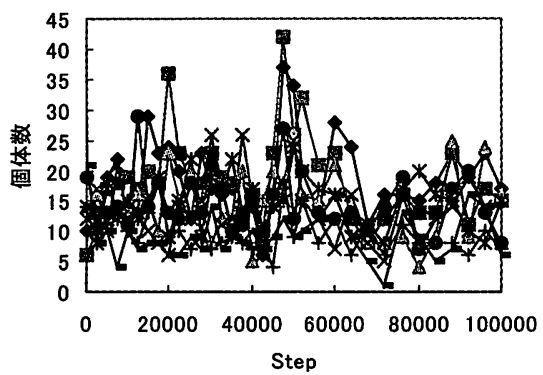

行動 イントロン有り
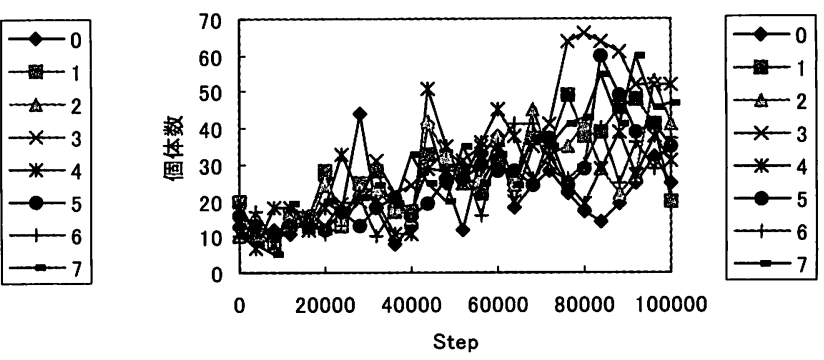

体色 イントロン有り
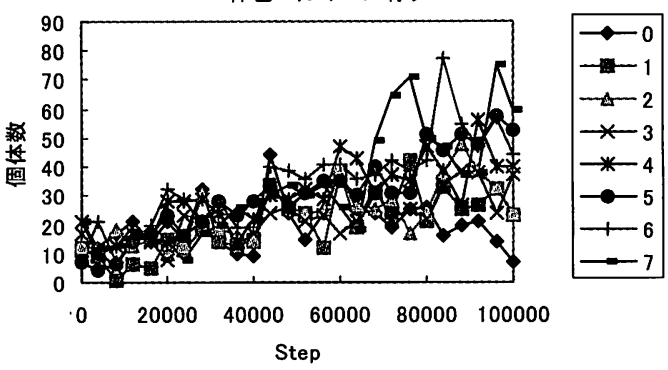

サイズ イントロン有り
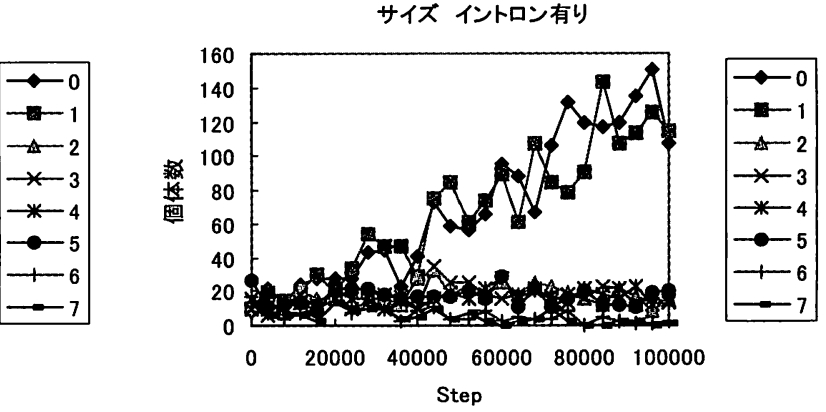

図 7 天敵が存在する場合の各特幑動向 
ントロンの突然変異に対するロバストネスが有効 に働いたとするならば，このイントロン長付加割 合は, 特徴の重要性を示唆していると考えられ る.よって, この環境下での重要度の順位も, サイズ”, “行動”, “体色”の順であると考えら れる、また，食料が5から 15 に増えることによっ て,さらに”サイズ”の重要性が増していると考 えられる。

\section{天敵が存在する場合}

図 5 右に食糧供給量が 15 で天敵が存在する場 合のイントロンが有る場合と無い場合の個体数変 化を, 図 7 に特徴の值ごとの個体数変化を示す. 天敵が存在することによって様子が複雑になる. 個体数は，ステップが少ない間はイントロンが有 る場合と無い場合ではほとんど差がない、ステッ プが進むにつれて，わずかにイントロンが有る方 が個体数が多くなっている. 天敵が存在しない場 合, “体色”は派手な方が，”サイズ”は小さい方 がより生き残る可能性が高かったが，天敵が存在 することによって，"体色”が派手なことによる 天敵と遭遇する確率の増大，“サイズ”が大きい ことによる被食率の減少という，相反寸る状況が 発生する.“行動”では, イントロンが有る場合, 無い場合共に，どの行動様式も優勢になっていな い。これは, 天敵が存在しない場合に, 優勢で あった”直進性の高い”ことが，天敵に出会い易 くなった為だと考えられる.“体色”についても, イントロンが有る場合でも前に述べたジレンマの 為に，どの色も優勢になっていない，ただ，イン

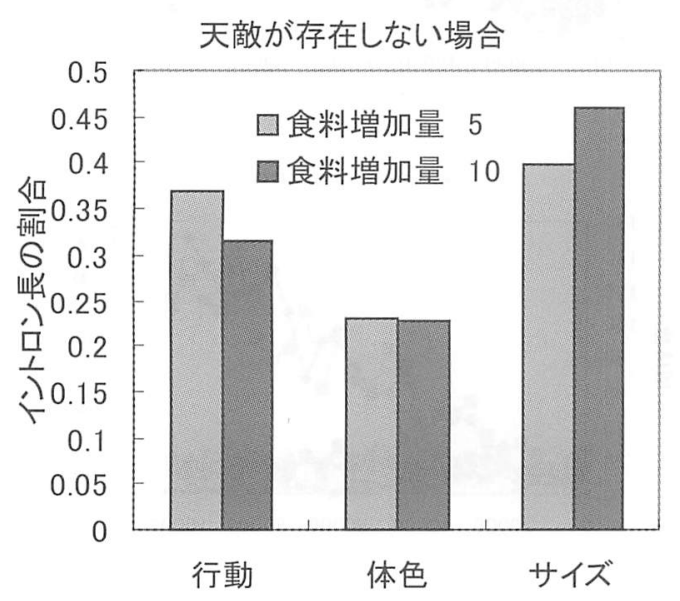

トロンが増大することにより，個体数の変化は 小さくなっている。"サイズ”については, イン トロンが無い場合でも，天敵が存在しない場合 に比べ，その傾向は弱くなっているが，やはり小 さな個体がやや優勢になっている，イントロン が有る場合では, ステップ数が少ないうちは, 違 いが見られないが，ステップ数が増えるに従っ て, 徐々にサイズの小さい個体が優勢になって いる.

図8右は, 天敵が存在する場合としない場合の イントロン付加割合をあらわしている。 天敵が 存在する場合の”サイズ”のイントロン付加割合 が，天敵が存在しない場合に比べて減少してい る.この理由として，天敵が存在することによ り, “サイズ”が小さいことによるエネルギー消 費が少ないとうメリットが，被食されやすいと いらデメリットと相殺されるため, “サイズ”の 重要度が減少したものと考えられる。

\section{実験2}

実験 1 で得られた各特徴に対するイントロン 長が,イントロン長合計が同じ個体に比べて, よ り環境に適応できるかどうかを実験した。天敵 が存在しない場合は, “行動”, “体色”, “サイ ズ”に対してそれぞれ，8，6，10 といったイン トロン長の個体と, イントロン長が獲得長に対 して $8 ， 8 ， 8$ の個体を比較した. 天敵が存在する 場合では, “行動”, “体色”, “サイズ”に対し てそれぞれ，6，5，7といったイントロン長の個

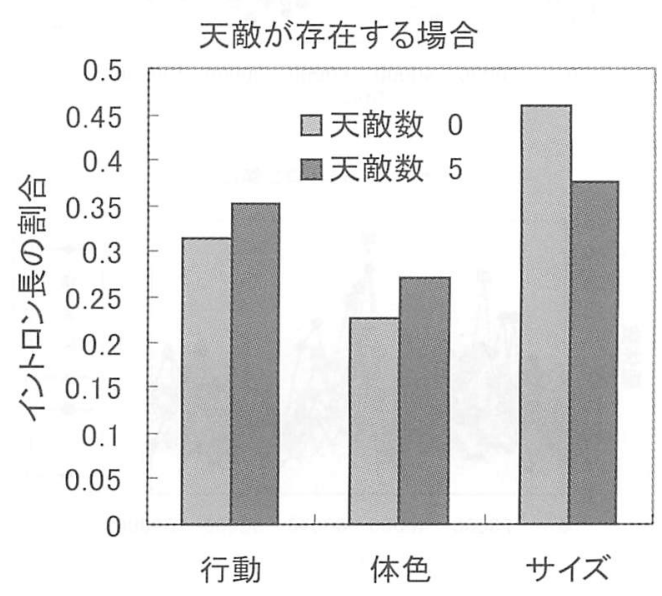

図8 各特徴のイントロン長割合 
体と，イントロン長が獲得長に対して 6，6，6の 個体を比較した。

\section{実験2の結果および考察}

図 9 にそれぞれ天敵が存在しない場合と天敵が 存在する場合の 50,000 ステップでの個体数の試 験 10 回の平均を示す. 兩方の環境で, 実験 1 で得 られたイントロン長を用いた個体の数の方が, よ り個体数が多くなっている。これは, 実験 1 で獲 得されたイントロン長の聟然変異に対するロバス トネスが有効に働いた結果だといえる.

\section{文字列探索問題を用いたDNAアルゴリズム と遺伝的アルゴリズムとの比較}

文字列探索問題を用いて, 突然変異率とイント ロン挿入確率の観点からD N A アルゴリズム （DNAA）と遺伝的アルゴリズム（GA）との比較を 行った.

\section{DNAアルゴリズム}

2 章より, 人工生命を用いてイントロン挿入の 意義を考察したが，この概念をGAに取り入れた のがDNAアルゴリズム（DNAA）である。つまり， 従来の GA ではエキソン部のみを考慮し，イント ロン部老考慮に入れていなかったが, DNAAでは, イントロン部考考虑に入れて, その効果老期待す る. 将来的には, DNAの配列自体の最適手法を最 適化アルゴリズムの手法として, 取り入れたいと 考えている.

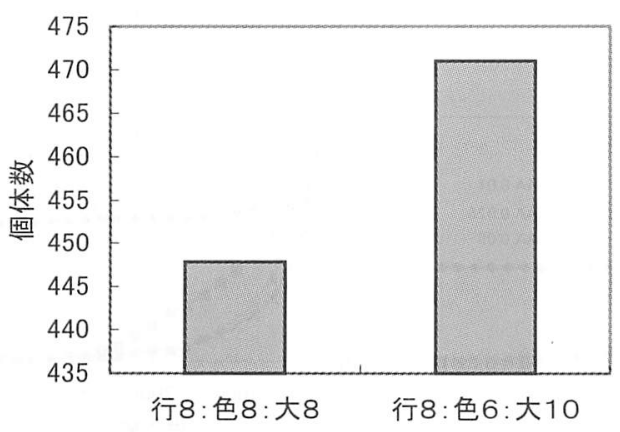

\section{文字列探索問題}

文字列探索問題とは，あるアルファベット 26 文字と空白から成る目標文字列を設定し，それ を䛊差，つまり何文字違っているかを用いて推 定する問題である。例えば，目標文字列が， ABCDE のとき, 推定文字列が ABZXE であれば誤差 は 2 となる。

\section{コーディングとオペレーション \\ コーディング}

DNAA，GAともに，文字自体をそれぞれDNAコー ド，遺伝子コードとして扱う。

交义，集団数と選択手法(DNAA，GAともに共通)

交叉は一点交叉とし, 集団数を 20 , 選択手法 をトーナメント方式とした。トーナメント方式 とは，集団のなかからある個体数（Stとする）を ランダムに選び出してその中で一番よいものを 選択する方式である。今回はStを 2 とした。適 忘度は, 目標文字列と推定文字列との誤差とし, 少ないほど良いと設定した。

イントロン挿入(DNAAのみ)

世代ごとに，ランダムに個体を選びイントロン をある確率（イントロン挿人確率）で挿人する. イントロンの長さは, 突然変異率に影響を与え る。突然変異に選ばれたビットの䓡変異率は 初期変異率老（イントロン長＋1）で除した值に 突然変異率の下限值を老加えた值である。ここ では $\varepsilon=0.001$ とした.

問題設定

目標文字列として，OSAKA_PREFECTURE_ UNIVERSITY老用いた。そして，それぞれのアル

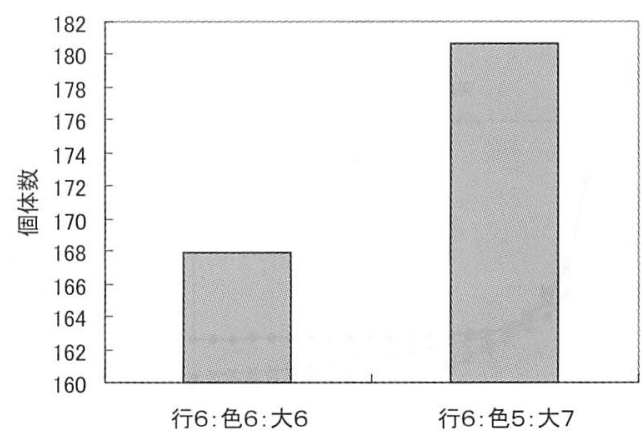

図 9 イントロン長差による個体数比較 
ゴリズムで突然変異率を変化させ，またDNAAに 於いては, イントロン挿入確率を変化させて, 文 字列探索問題を解いた.

\section{結果と考察}

図 10 に突然変異率ごとの遺伝的アルゴリズム とイントロン挿入確率が $0.001 ， 0.025$, そして 0.05 の DNAA アルゴリズムの誤差減少の様子を示 す. 突然変異率が 0.001 の場合, 世代数が少ない 時点では, GA の誤差が一番速く減少しており，世 代が進むにつれてイントロン挿入確率 0.05 の DNAA の誤差減少がやや遅くなっている。 これは, イントロン挿入が過多になり突然変異による解の 改良を妨げているためだと考えられる. 突然変異 率 0.005，0.001 ともに GA が最も速く誤差が減少 し，DNAAに於いては，イントロン挿入確率が低い 順に誤差減少速度が速くなっている．このことか らこの文字列探索問題では， $\mathrm{GA}$ にとってこのあ たりの突然変異率が最適と考えられる，突然変異 率が 0.05 以上の場合，GA では誤差がある值から 減少しなくなり，その值は突然変異率が上がると 共に大きくなった. この理由として, 高すぎる突
然変異率が今まで推定してきた良い解を破壊し てしまうためだと考えられる．それに対しDNAA では突然変異率が高くなるにつれ誤差減少速度 は遅くなるものの，世代数 3000 程で，ほぼ誤差 を0にすることに成功した．これは，世代数が増 えるにつれて, イントロンが長くなるため, 突然 変異率の弊害を緩和するためだと考えられる. 以上の結果より，DNAA はより，GAに比べ，より 高い突然変異率に対し安定して目標文字列を推 定することができることがわかった

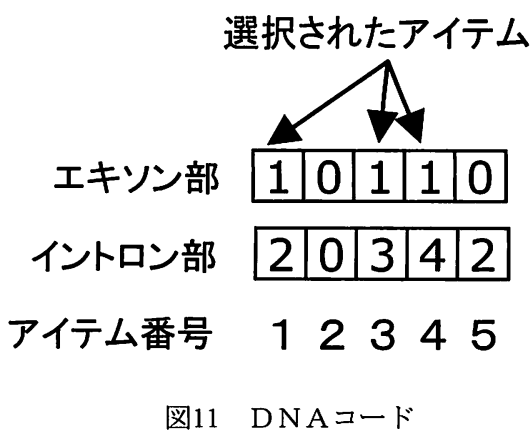

図11 DNAコード
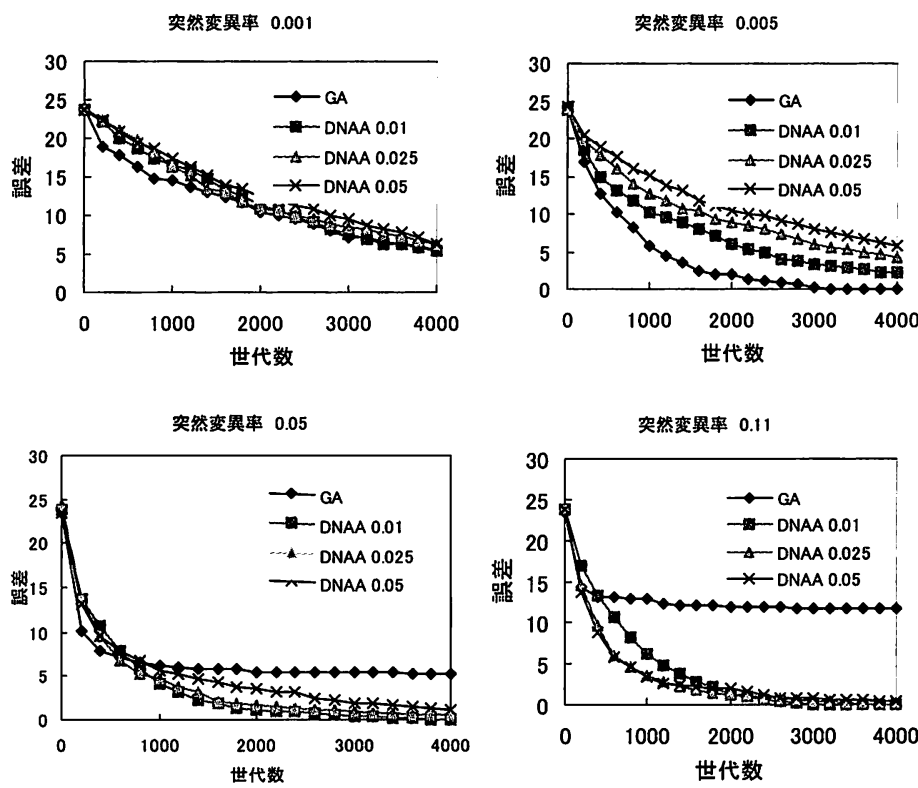

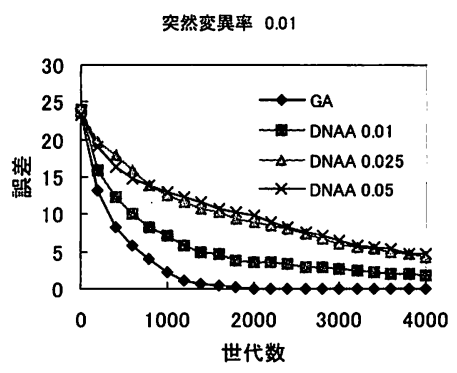

突然変畏率 015

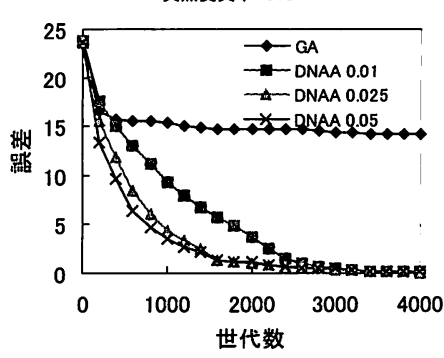

図10 突然変異率と誤差減少の様子 


\section{ナップザック問題を用いたDNAアルゴリズ ムの検証}

次に，「イントロンがエキソン部を保護するの であれば，より重要なエキソン部にはより長いイ ントロンが付加するのではないか」という仮説 を，ナップザック問題を用いて検証した。ナップ ザック問題は, 複数の物体（個々の物体は異なる 重さと価值を持つ）が与えられた時に，重さがあ る範囲以内でいくつかの物体を選択し，その時の 価值の合計が最大になるような選択の方法を見つ けるという問題である（北野 1993）.

\section{DNAアルゴリズムの設定}

基本的に，GA と同じである.オペレーションと して, 選択, 交叉, 突然変異, そしてイントロン の挿入がある。

コーデイング

解をビット列であらわし，i番目のビットが i 番目の物体に対応しており，選択される場合は 1 で選択されない場合は0で表される。さらに，そ れぞれのビットには, 対応するイントロンが存 在する. 例えば図 11 の DNA モデルの場合, 番号 が 1，3，5のアイテムが選択されたことを表し， 1 番目のエキソン部を保護するイントロン長は 2 である。

交叉

ランダムに集団内から選ばれた 2 個体が交义寸 る，交叉は一点交叉とする。

突然変異

ランダムに，個体と遺伝子座を選び，ビットを 反転させる。その時の突然変異率は，突然変異

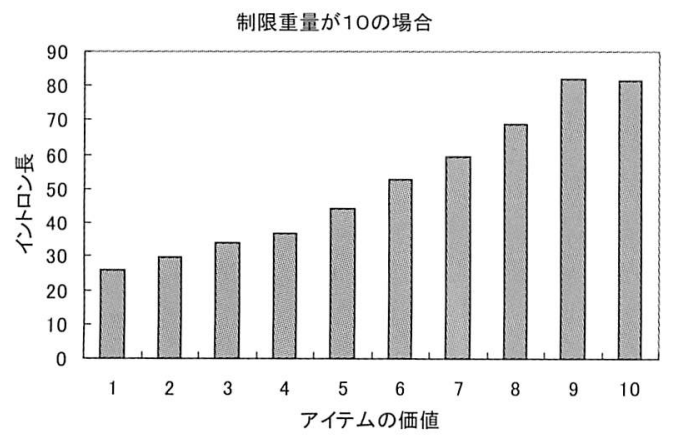

率/（イントロン長＋1）で表される，また，突 然変異を受けたエキソン部のイントロン長は, 0 になる。

選択

個体群は，合計価值の高い順に並べ替えられ る、ただし，制限重量を超えた個体は，ペナル ティーとして合計価值を 0 として計算する。下位 から決まった個体数を，ランダムに生成された 新しい個体と入れ替える.

イントロンを長くする

ランダムに，個体とエキソン部を選び，それを 保護するイントロンを一つ長くする.

\section{問題設定}

重量がそれぞれ 1 ，価值が $1 ， 2 ， 3 ， 4 ， 5 ， 6$, 7，8，9 そして 10 の 10 個の物体を考える. 集団 個体数を 20 , 交叉率 0.6 , 突然変異率 0.1 , イン トロン挿入確率を 0.2 とした. 各実験を, 100 回 ずつ行った.

実験

制限重量を10，すなわち全ての物体を選択で きる場合を検証した。

実験2

制限重量を 5 ，才なわち 5 個の物体を選択でき る場合を検証した。

\section{結果と考察2}

図 12 左図が実験 1 の結果を表している。縦軸 は，それぞれの物体を保護するイントロンの長 さを全体のイントロンの長さで割った值である. 価值が上がるにつれてイントロンが長くなる傾 向が見られる。価值の高い物体を選択しない場

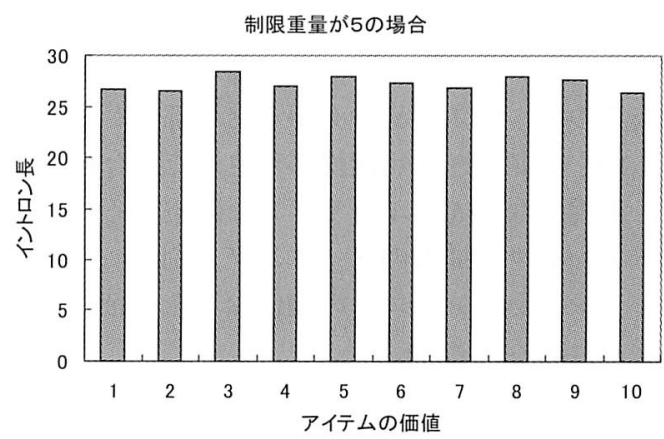

図12 各エキソン部を保護するイントロン長の割合 
合，次の世代に生き残るのが困難になるために, 突然変異に対して耐性を持った個体が選ばれた ためだと考えられる.つまり，イントロン長がそ れに対応するエキソン部の重要度を示している と考えられる.

図 12 右図は実験 2 の結果を表している. 制限重 量を 5 にした場合では，価值が高い物体を選ぶこ とと，価值が低い物体を選ばないことが重要であ ることから，それらの物体を表すエキソン部にイ ントロンが他よりも多く付加するのではと予想し たが，イントロン長の差は認められなかった.こ れは，実験 1 ほどに最適解が明確でないために集 団内での適応度差が淘汰に反映されなかったた め, イントロンによる突然変異への耐性の効果が 有効に働かなかったためだと考えられる. 今回用 いたナップザック問題は，非常に簡略化したもの であるが, イントロン長がエキソン部の重要部の 指標となるのではないかという 2 章で示した結果 を裏付ける結果となった。

\section{まとめ}

本研究では簡単な人工生命を用いて, イントロ ンの役割とイントロン長の意義を検討した，その 結果, イントロンによる環境に適応した形質の突 然変異からの保護が個体数を増やす上で有効であ ること, さらに, イントロンをランダムに挿入し ていっても, 結果的に重要な形質を守るイントロ ンほど長くなる傾向があることが分かった．その 概念を用いたDNA アルゴリズムで文字列探索問題 を解いたところ, 高い突然変異率に設定した場合 でも遺伝的アルゴリズムに比べて，より安定して 目標文字列の推定に成功した.さらに, ナップ ザック問題に適用したところ, 最適解を求める際 に, 重要な部分ほどイントロン長が長くなる傾向 があるので, 解ストリングからどの部位が重要で あるかを推測できる可能性が示された．今後さら に, 実用的な DNA アルゴリズムを開発するために は, イントロン挿入のタイミング, 割合, そして エキソン部とイントロンの関係などを検証してい かなければならない.

\section{引用文献}

伊庭斉志 (1994)遺伝的アルゴリズムの基礎一GAの謎を解 く一, オーム社, 221-240.

ジョン・メイナード=スミス (1995)進化遺伝学, 産業図 書, 230PP.

北野宏明編(1993)遺伝的アルゴリズム, 産業図書, 135140, 287-304.

小畠郁生監修 (1998) 進化論の不思議と謎, 日本文芸社, 184-188.

受付日: 2002 年 9 月 11 日

受理日: 2003 年 1 月 16 日 


\title{
DNA Algorithms
}

\section{Tsuyoshi Okayama, Hiroshi Kitabata and Haruhiko Murase}

\author{
Osaka Prefecture University
}

Graduate School of Agriculture and Biological Sciences 1-1, Gakuen-cho, Sakai, 599-8531 Japan

\section{Summary}

Recently, genetic algorithms(GAs) have received a lot of attention because of their easy-to-use features for solving many engineering problems. They are capable of locating a good approximation in extremely large search spaces with a reasonable amount of computational effort. In this study, we have developed DNA algorithms(DNAAs). The distinction between GAs and DNAAs comes from the fact that GAs take into account only exons whereas DNAAs are concerned about not only exons but also introns. Exons are parts of genes embedded in DNA. Introns are the segments of DNA remaining after the removal of genes. It is said that exons do not contain any information for protein synthesis. It speculated that introns might have some hidden roles. If all parts of DNA had important information, mutations or mal-duplication would be expected to cause fatal problems. It can be hypothesized that introns, therefore, serve as protection for exons against mutations. On basis of this hypothesis, we investigated the role of introns by using an artificial life. Then a string search problem and a knapsack problem were solved by DNAAs in order to evaluate performance of DNAAs. DNAAs performed robustly even under a fairly high ratio of mutation. It was also found that more introns were accumulated near exons whose role seemed more important than other exons.

\section{Keywords}

artificial life, biosystem derived algorithms, genetic algorithms, intron, DNA 